ISSN 0258-7122

Bangladesh J. Agril. Res. 38(4): 599-612, December 2013

\title{
CHARACTER ASSOCIATION AND PATH CO-EFFICIENT ANALYSIS IN Brassica rapa $\mathrm{L}$.
}

\author{
M. H. KHAN ${ }^{1}$, S. R. BHUIYAN ${ }^{2}$ AND F. MAHMUD ${ }^{3}$
}

\begin{abstract}
The experiment was carried out with 32 genotypes of Brassica rapa including two commercially cultivated varieties as checks to study their mean, range, cv (\%) correlation co-efficient, and path co-efficient considering 10 different morphological characters at the experimental farm of SAU, Dhaka during November 2009 to February 2010. Significant variation was observed among all the genotypes for all the characters studied except 1000-seed weight. In general, genotypic correlations were higher than the phenotypic correlations. It indicates that there was an inherent association among them which was adversely influenced by the environment. Days to flowering showed positive significant correlation with days to maturity. Plant height showed positive significant correlation with number of primary branches/plant. Number of primary branches/plant showed positive significant correlation with siliquae/plant. Length of siliquae showed positive significant correlation with seeds/siliquae. Number of secondary branches, number of siliquae/plant, days to maturity, seeds/siliquae, and 1000-seed weight showed positive significant association with yield/plant. Path analysis showed that number of primary branches/plant, number of siliquae/plant, number of secondary branches/plant, and number of seeds/siliquae had direct effect on seed yield/plant. Considering analytical findings of correlation co-efficient, path co-efficient analysis and field performance, the genotypes G-15, G-19, G-1, G-3, G-4, G-10, G-18 G-21, and G-24 would be suitable for future hybridization programme.
\end{abstract}

Keywords: Character association, path co-efficient analysis, B. rapa.

\section{Introduction}

Rapeseed-mustard is a major oilseed crop in Bangladesh. It contributes a lion share to the total edible oil production in the country. Most of the developed varieties take long duration to mature except a few. As a result, they do not fit well in the existing T.aman - Mustard - Boro cropping pattern. Brassica have great economic and commercial value and play a major role in our daily diet. Fat and oil are vital components of the human diet because they are important sources of energy and act as a carrier of fat soluble vitamins. Poor intake of fat and oil reduce the availability of fat soluble vitamins and caused dietary imbalance and food wastage. In a balanced diet, $20-25 \%$ of calories should come

${ }^{1}$ Scientific Officer (Plant Breeding), Oilseed Research Centre, Bangladesh Agricultural Research Institute (BARI), Gazipur, ${ }^{2 \& 3}$ Professor, Dept. of Genetics \& Plant Breeding, Sher-e- Bangla Agricultural University, Dhaka, Bangladesh. 
from fats and oils and the average need of fats and oils is about $37 \mathrm{~g} / \mathrm{day}$ (Rahman, 1981). The seeds of Brassica rapa contain $42 \%$ oil and $25 \%$ protein (Khaleque, 1985).There is limited scope of horizontal expansion of cultivation of mustard. So, for increasing mustard production, yield must be increased in per unit area. Developing high yielding varieties in mustard, this demand can be met up. Therefore, high yielding and short duration rapeseed and mustard varieties should be developed to fit into the existing cropping pattern. Thus $\mathrm{F}_{8}$ materials have been generated through different inter varietal crosses of Brassica juncea and the present study was conducted to find out the variability, character association, and the direct and indirect effect of different characters on yield/plant which will give an opportunity to select the desired plant types to meet the existing demand. Determination of correlation co-efficient between the characters has a considerable importance in selecting breeding materials. The path co-efficient analysis gives more specific information on the direct and indirect influence of each of the component characters upon seed yield (Behl et al., 1992). Selection of grain yield becomes difficult unless the association among the yield contributing characters are known. So estimation of correlation helps to identify the relative contribution of component characters towards yield (Panse, 1957). As yield is the main objective to a breeder, it is important to know the relationship among various characters that have direct and indirect effect on yield. Yield components influence the ultimate yield of a crop both directly and indirectly (Turkey, 1954). Path analysis specifies the causes and effect relationship and measures the relative importance of each variable (Wright, 1959). Therefore, correlation in combination with path co-efficient analysis will be an important tool to find out the association between direct and indirect effects and quantify the direct and indirect influence of one character upon another (Dewey and Lu, 1959). The correlation co-efficient between yield and yield contributing characters usually show a complex chain of interacting relationship. Path co-efficient estimates the direct and indirect effects of different yield contributing characters towards the yield through correlation co-efficient analysis and visualizes the relationship in more meaningful way. Therefore, the present study was undertaken to find out and establish suitable selection criteria for higher yield through study of variability and relationship between yield and yield components in Brassica rapa.

\section{Materials and Method}

The present experiment was conducted at the experimental farm of Sher-eBangla Agricultural University, Dhaka-1207 during November 2009 to February 2010. A total number of 32 materials were used in this experiment where two were parents, thirty were $F_{7}$ generations (Table 2). The crop was fertilized at the rate of 10 tons of cowdung, $250 \mathrm{~kg}$ urea, $175 \mathrm{~kg}$ triple super phosphate (TSP), 85 
kg muriate of potash (MoP), $250 \mathrm{~kg}$ gypsum, $3 \mathrm{~kg}$ zinc oxide, and boron $1 \mathrm{~kg}$ per hectare. The half amount of urea, total amount of cowdung, TSP, MoP, gypsum, zinc oxide, and boron were applied during final land preparation. The rest amount of urea was applied as top dressing after 25 days of sowing. The experiment was laid out in randomized complete block design (RCBD) with three replications. The total area of the experiment was $37 \mathrm{~m} \times 11 \mathrm{~m}=407 \mathrm{~m}^{2}$. Each replication size was $37 \mathrm{~m} \times 2.7 \mathrm{~m}$, total plot size was $299.7 \mathrm{~m}^{2}$ and the distance between replication to replication was $1 \mathrm{~m}$. The spacing between line to line was $30 \mathrm{~cm}$. Seeds were sown in lines in the experimental plots on 04 November 2009. The seeds were placed at about $1.5 \mathrm{~cm}$ depth in the soil. Intercultural operations, such as weeding, thinning, irrigation, pest management, etc. were done uniformly in all the plots. Aphid infection was found in the crop during the siliquae development stage. To control aphids, Malathion-57 EC @ $2 \mathrm{ml} /$ liter of water was applied. Harvesting was done from $4^{\text {th }}$ to $15^{\text {th }}$ February 2010 depending upon the maturity.

For studying different genetic parameters and inter-relationships, ten characters were taken into consideration. The data were recorded on randomly ten selected plants for each of the parental line and $\mathrm{F}_{8}$ progenies on the following traits- days to $50 \%$ flowering, days to $80 \%$ maturity, plant height $(\mathrm{cm})$, number of primary branches/plant, number of secondary branches/plant, number of siliquae/plant, siliquae length $(\mathrm{cm})$, number of seeds/siliquae, 1000 -seed weight (g), seed yield/plant (g). The data were analyzed for different components. Phenotypic and genotypic variance was estimated by the formula used by Johnson et al. (1955). Genotypic and phenotypic co-efficient of variation were calculated by the formula of Burton (1952). Simple correlation coefficient was obtained using the formula suggested by Clarke (1973); Singh and Chaudhary (1985). Genotypic and phenotypic correlation co-efficient were calculated following Miller et al. (1958). Path co-efficient analysis was done following the method outlined by Dewey and Lu (1959). Statistical analysis were done using Genstat 5 Release 4.1 software program (copyright 1997, Lawes Agricultural Trust, Rothamasted Experimental Station, UK).

\section{Results and Discussion}

The mean, range, and cv (\%) for seed yield and yield contributing characters of 32 genotypes of Brassica rapa along with checks are presented in Table 1. Variations were observed among the lines for all the characters studied. Days to $50 \%$ flowering ranged from 30.33 to 36.00 . Highest days to flowering were observed in genotype $G_{1}$ and the lowest was genotype $G_{17}$ and $G_{19}$. Plant height ranged from $74.33 \mathrm{~cm}$ to $118.33 \mathrm{~cm}$. Highest plant height was observed in genotype $G_{19}(118.33 \mathrm{~cm})$ and lowest was in genotype $G_{23}(74.33 \mathrm{~cm})$. Number of primary branches/plant ranged from 4.20 to 9.40 . Highest number of primary 
branches/plant was observed in genotype $G_{10}$ (9.40) and the lowest was in genotype $G_{23}$ (4.20). Number of secondary branches/plant ranged from 1.33 to 8.47. Highest number of secondary branches/plant was observed in genotype $\mathrm{G}_{8}$ (8.47) and the lowest was in genotype $G_{16}$ and $G_{19}$ (1.33). Number of siliquae/plant ranged from 68.33 to 228.00 . Highest siliquae/plant was recorded in genotype $G_{3}$ (228.00) and the lowest was in genotype $G_{16}$ (68.33). Length of siliquae ranged from 4.34 to $6.93 \mathrm{~cm}$. Highest length of siliquae was observed in genotype $\mathrm{G}_{15}(6.93 \mathrm{~cm})$ and the lowest was in genotype $\mathrm{G}_{14}(4.34 \mathrm{~cm})$. Days to $80 \%$ maturity ranged from 86.33 to 97.33 . Genotype $G_{8}$ (86.33) showed early maturity and genotype $G_{1}$ (97.33) was found late in maturity. Number of seeds/siliquae ranged from 12.30 to 24.33 . Highest number of seeds/siliquae was observed in genotype $G_{21}$ (24.33) and the lowest was observed in genotype $G_{14}$ (12.30). Thousand seed weight ranged from 3.11 to 4.50g. Highest 1000-seed weight was recorded in genotype $G_{19}(4.50 \mathrm{~g})$ and the lowest was in genotype $G_{25}$ (3.11g). Seed yield/plant ranged from 5.23 to $9.87 \mathrm{~g}$. The highest seed yield/plant was recorded in genotype $G_{15}(9.87 \mathrm{~g})$ and the lowest was recorded in genotype $\mathrm{G}_{5}$ (5.23g) Table 2.

The percent of highest co-efficient of variation (CV \%) was recorded in the character number of secondary branches/plant (53.77) followed by the character number of siliquae/plant (27.11) and 1000-seed weight (20.61). Minimum variation was observed in the character days to 80\% maturity (1.36) Table 1.

Table 1. Mean Range and CV (\%) of seed and yield contributing characters 32 genotypes of Brassica rapa.

\begin{tabular}{l|c|c|c|c|c}
\hline Characters & MS & Mean & Range & CV (\%) & SE \\
\hline DTF & 5.58 & 32.30 & $30.33-36.00$ & 4.02 & 0.18 \\
PHT & 275.83 & 96.89 & $74.33-118.33$ & 7.22 & 1.14 \\
NPB & 4.2 & 6.13 & $4.20-9.40$ & 18.24 & 0.15 \\
NSB & 12.67 & 4.83 & $0.50-8.47$ & 53.77 & 0.31 \\
NSP & 4599.79 & 153.28 & $68.33-228.00$ & 27.11 & 5.26 \\
PLH & 0.68 & 5.51 & $4.34-6.93$ & 8.16 & 0.06 \\
DEF & 19.94 & 90.50 & $86.33-97.33$ & 1.36 & 0.28 \\
SPS & 18.66 & 16.61 & $12.30-24.33$ & 15.66 & 0.34 \\
TSW & $0.39 \mathrm{~ns}$ & 3.57 & $3.11-4.50$ & 20.61 & 0.07 \\
YPP & 4.95 & 7.61 & $5.23-9.67$ & 20.42 & 0.19 \\
\hline
\end{tabular}

DTF $=$ Days to $50 \%$ flowering, $\mathrm{PHT}=$ Plant height $(\mathrm{cm}), \mathrm{NPB}=$ No. of primary branches/plant, NSB $=$ No. of secondary branches/plant, NSP = No. of Siliquae/plant, PLH = Length of Siliquae $(\mathrm{cm})$, DEF $=$ Days to $80 \%$ maturity, SPS $=$ No. of seeds/siliquae, TSW $=1000$ seed weight $(\mathrm{g})$ and YPP $=$ Seed yield/plant $(\mathrm{g}) . \mathrm{ns}=$ Not significant. \% CV = Percent co-efficient of variation. 


\section{Correlation co-efficient}

Seed yield is a complex product being influenced by several quantitative traits. Some of these traits are highly associated with seed yield. The analysis of the relationship among those traits and their association with seed yield is very much essential to establish selection criteria. Breeders always look for genetic variation among traits to select desirable type. Correlation co-efficient between pairs of trait for $\mathrm{F}_{7}$ materials of B. rapa are shown in (Table 3).

Days to flowering showed positive significant correlation with days to maturity $(\mathrm{G}=0.838, \mathrm{P}=0.571)$, followed by positive values with number of secondary branches/plant $(G=0.389, P=0.132)$, siliquae/plant $(G=0.560, P=$ 0.192), days to maturity ( $G=0.838, P=0.571)$, and non-significant with length of siliquae $(G=0.001, P=0.081)$, plant height $(G=0.074, P=0.099)$, and yield/plant $(G=0.292, P=0.033)$. Whereas negative significant correlation was found in number of primary branches/plant $(G=-0.128)$ followed by 1000 -seed weight $(\mathrm{G}=-0.910, \quad \mathrm{P}=-0.135)$ and non-significant correlation with seeds/siliquae ( $\mathrm{G}=-0.034, \mathrm{P}=-0.040)$, (Table 3). Singh et al. (1987) and Shivahare et al. (1975) reported that days to 50\% flowering negatively correlated with 1000-seed weight.

Plant height showed positive significant correlation with number of primary branches/plant $(\mathrm{G}=0.901, \mathrm{P}=0.585)$ followed by positive values with yield/plant $(G=0.479, P=0.385)$ and seeds/siliquae $(G=0.523, P=0.375)$ and non-significant with siliquae/plant $(G=0.245, P=0.236)$, length of siliquae $(G=$ $0.234, P=0.182)$, and 1000 -seed weight $(G=0.281, P=0.066)$. Whereas negative significant correlation was found in number of secondary branches/plant $(G=-0.306, P=-0.110)$ followed by days to maturity $(G=-0.109, P=-0.058)$, (Table 3).These findings have close resemblance with the reports of Chowdhury et al. (1987) and Yadava et al. (1978).

Number of primary branches/plant showed positive significant correlation with siliquae/plant $(P=0.953)$ followed by yield/plant $(G=0.760, P=0.394)$, seeds/siliquae $(G=0.561, P=0.286)$ and non-significant with length of siliquae $(\mathrm{G}=0.331, \mathrm{P}=0.189)$, number of secondary branches/plant $(\mathrm{G}=0.209, \mathrm{P}=$ $0.063)$, and 1000 -seed weight $(G=0.136)$. Whereas negative non-significant correlation was found in siliquae/plant $(G=-0.202)$ followed by days to maturity $(\mathrm{G}=-0.062, \mathrm{P}=-0.020)$ and 1000 -seed weight $(\mathrm{P}=-0.007)$ (Table 3$)$.

Number of secondary branches/plant showed positive significant correlation with yield/plant $(G=0.626, P=0.326)$, followed by siliquae/plant $(G=1.110$, $\mathrm{P}=0.527)$ and non-significant with days to maturity $(\mathrm{G}=0.313, \mathrm{P}=0.151)$ and length of siliquae $(P=0.082)$, Whereas negative significant correlation was found in seeds/siliquae $(G=-0.871, P=-0.131)$ followed by length of siliquae ( $G$ $=-0.136)$ and 1000 -seed weight $(\mathrm{G}=-1.049, \mathrm{P}=-0.001)$ (Table 3). 
Table 2. Mean performance of 32 genotypes of Brassica rapa.

\begin{tabular}{|c|c|c|c|c|c|c|c|c|c|c|c|}
\hline Genotype & & DTF & PHT & NPB & NSB & NSP & PLH & DEF & SPS & TSW & YPP \\
\hline F6 × BARI 9 P2 & $\mathbf{G}_{2}$ & 35.00 & 93.00 & 5.33 & 6.50 & 168.00 & 6.18 & 96.33 & 19.67 & 3.40 & 7.93 \\
\hline BARI 6 × R.Tori 7 & $\mathrm{G}_{4}$ & 34.67 & 100.33 & 7.03 & 8.03 & 215.00 & 5.67 & 94.00 & 15.00 & 3.17 & 9.53 \\
\hline BARI $9 \times$ BARI 6 P7 & $\mathbf{G}_{5}$ & 33.67 & 91.57 & 5.50 & 5.67 & 147.00 & 5.77 & 95.00 & 17.97 & 3.40 & 7.32 \\
\hline BARI $9 \times$ BARI6 P4 & $\mathbf{G}_{7}$ & 32.33 & 92.67 & 5.80 & 4.10 & 135.00 & 5.47 & 88.00 & 14.67 & 3.43 & 6.80 \\
\hline SAU Sharisa 1 S3 & $\mathrm{G}_{8}$ & 31.00 & 99.00 & 5.57 & 8.47 & 157.00 & 6.03 & 86.33 & 16.00 & 4.23 & 7.50 \\
\hline BARI $9 \times$ BARI 6 P3 & $\mathrm{G}_{9}$ & 34.33 & 100.30 & 4.30 & 4.27 & 153.67 & 5.28 & 89.00 & 14.97 & 4.05 & 7.83 \\
\hline F6 × BARI 9 & $\mathrm{G}_{10}$ & 32.00 & 117.67 & 9.40 & 5.23 & 214.67 & 5.67 & 89.67 & 17.67 & 3.20 & 9.03 \\
\hline BARI 9 × F6 P6 & $\mathrm{G}_{14}$ & 33.00 & 98.30 & 5.57 & 3.47 & 145.17 & 4.34 & 88.67 & 12.30 & 3.48 & 5.83 \\
\hline SAU Sharisa 1 S1 & $\mathbf{G}_{15}$ & 31.00 & 112.67 & 9.00 & 2.33 & 140.67 & 6.93 & 88.00 & 21.67 & 3.80 & 9.87 \\
\hline BINA Sharisa 6 & $\mathrm{G}_{16}$ & 33.00 & 99.33 & 6.27 & 1.33 & 68.33 & 5.77 & 92.33 & 20.00 & 4.00 & 6.30 \\
\hline F6 ×BARI 9 P1 & $\mathbf{G}_{17}$ & 30.33 & 87.33 & 4.97 & 6.57 & 174.67 & 5.17 & 90.67 & 14.67 & 4.10 & 7.03 \\
\hline Tori 7× F6 P2 & $\mathrm{G}_{18}$ & 33.00 & 106.67 & 6.30 & 6.23 & 200.00 & 5.43 & 88.00 & 15.67 & 3.50 & 7.87 \\
\hline SAU Sharisa 1 S2 & $\mathrm{G}_{19}$ & 30.33 & 118.33 & 8.47 & 1.33 & 132.00 & 5.50 & 87.67 & 19.67 & 4.50 & 8.07 \\
\hline BARI 9 × F6 P5 & $\mathrm{G}_{20}$ & 32.67 & 87.67 & 6.60 & 7.33 & 172.33 & 5.20 & 91.33 & 16.67 & 3.63 & 9.20 \\
\hline
\end{tabular}




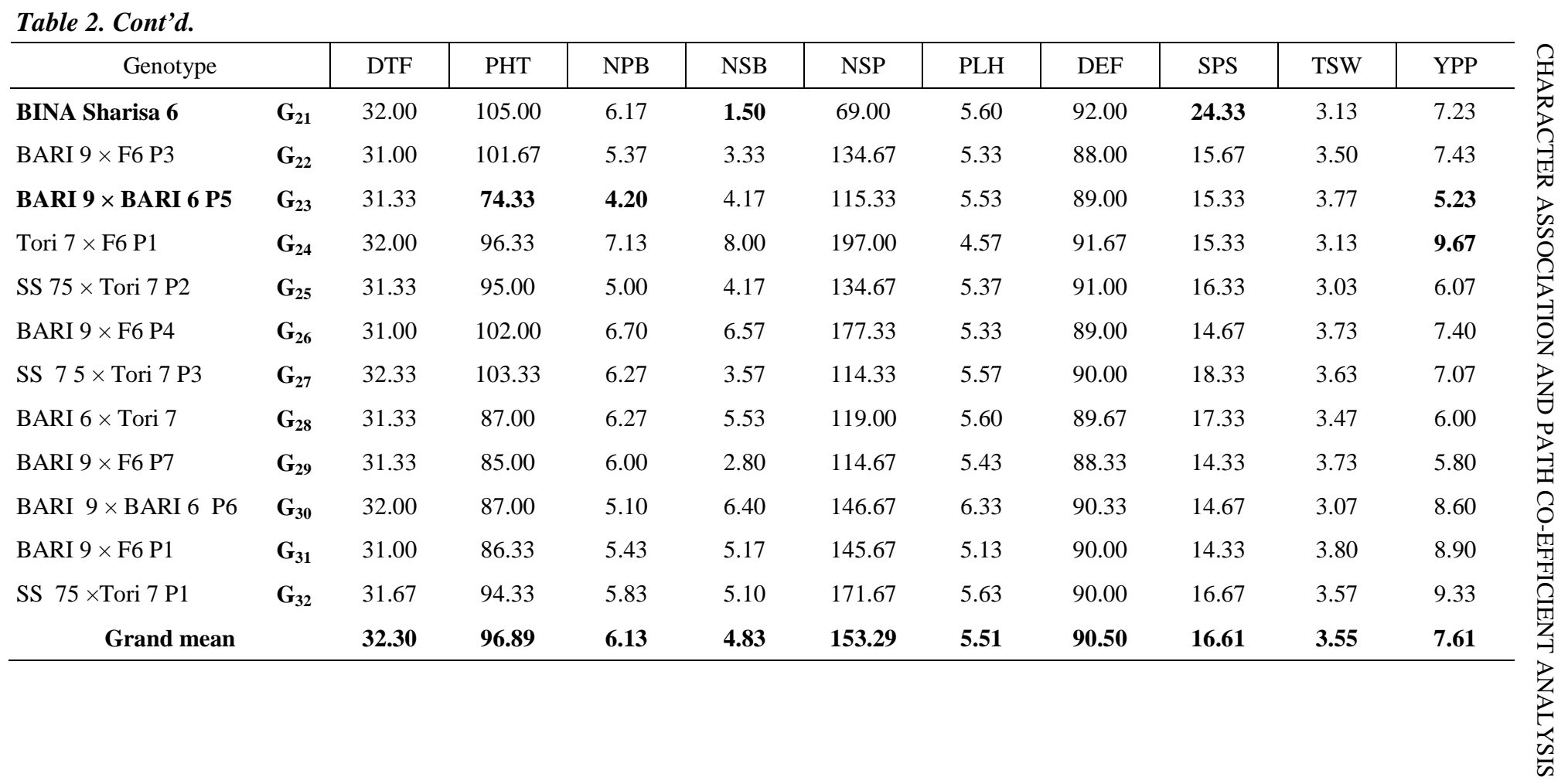


Table 3. Genotypic and phenotypic Correlations co-efficient among different characters of the $32 \mathbf{F}_{7}$ materials of Brassica rapa.

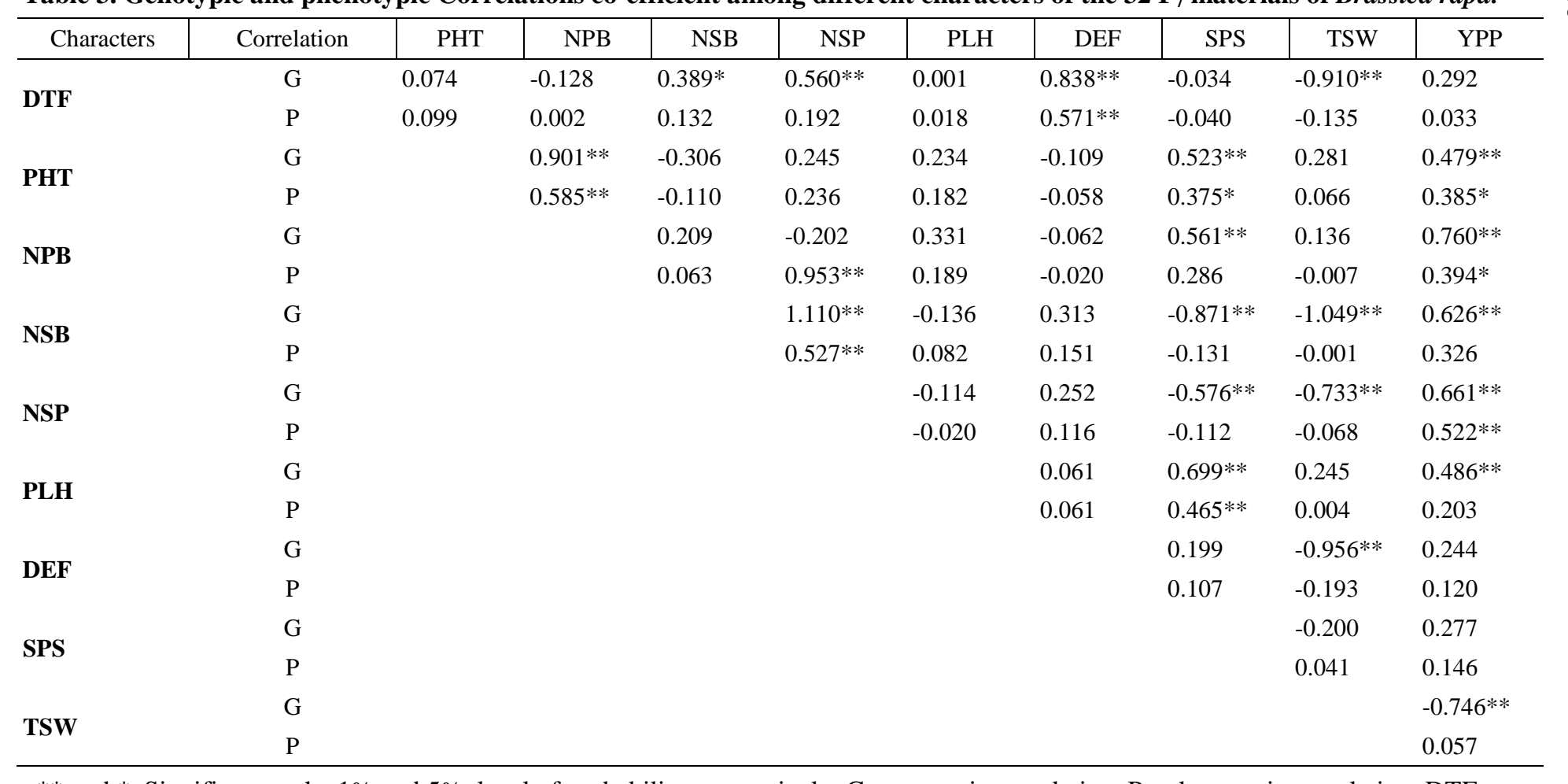

** and * Significant at the $1 \%$ and $5 \%$ level of probability, respectively, $\mathrm{G}=$ genotypic correlation, $\mathrm{P}=$ phenotypic correlation, $\mathrm{DTF}=$ Days to 50\% flowering, PHT= Plant height $(\mathrm{cm})$, NPB =No. of primary branches/plant, NSB = No. of secondary branches/plant, NSP = No. of Siliquae per plant, PLH = Length of Siliquae $(\mathrm{cm}), \mathrm{DEF}=$ Days to $80 \%$ maturity, SPS $=$ No. of seeds per Siliquae, TSW $=1000$ seed weight (g) and YPP = Seed yield per plant (g) 
Table 4. Path coefficient analysis showing direct and indirect effect of yield components on seed yield in $32 F_{7}$ materials of Brassica rapa.

\begin{tabular}{lllllllllll}
\hline \multicolumn{1}{c}{ Characters } & DTF & PHT & NPB & NSB & NSP & PLH & DEF & SPS & TSW & YPP \\
\hline DTF & $\mathbf{- 1 . 5 2 1}$ & 0.116 & 0.159 & 0.321 & 0.310 & 0.000 & 0.525 & 0.025 & 0.407 & 0.292 \\
PHT & 0.113 & $\mathbf{1 . 5 7 2}$ & 1.116 & 0.253 & 0.136 & 0.061 & 0.069 & 0.386 & 0.125 & $0.479 * *$ \\
NPB & 0.195 & 1.417 & $\mathbf{- 1 . 2 3 9}$ & -0.181 & 0.167 & 0.086 & -0.039 & 0.414 & -0.061 & $0.760^{* *}$ \\
NSB & -0.591 & -0.480 & 0.271 & $\mathbf{0 . 8 2 7}$ & 0.614 & -0.036 & 0.196 & 0.643 & 0.469 & $0.626 * *$ \\
NSP & -0.851 & 0.386 & -0.374 & 0.917 & $\mathbf{0 . 5 5 3}$ & -0.030 & 0.158 & 0.425 & 0.328 & $0.661 * *$ \\
PLH & -0.002 & 0.368 & -0.410 & -0.113 & -0.063 & $\mathbf{0 . 2 6 1}$ & 0.038 & 0.516 & -0.109 & $0.486 * *$ \\
DEF & -1.274 & -0.172 & 0.076 & 0.258 & 0.139 & 0.016 & $\mathbf{0 . 2 6 2}$ & 0.147 & 0.427 & 0.244 \\
SPS & 0.052 & 0.823 & -0.694 & -0.720 & -0.319 & 0.183 & 0.125 & $\mathbf{0 . 7 3 8}$ & 0.089 & 0.277 \\
TSW & 1.383 & 0.441 & -0.168 & -0.867 & -0.405 & 0.064 & -0.599 & 0.148 & $\mathbf{- 0 . 4 4 7}$ & $-0.746 * *$ \\
\hline
\end{tabular}

\section{Bold faces are direct effect}

DTF $=$ Days to $50 \%$ flowering, PHT= Plant height $(\mathrm{cm})$, NPB $=$ No. of primary branches/plant, NSB $=$ No. of secondary branches/plant, NSP $=$ No. of Siliquae per plant, PLH $=$ Length of Siliquae $(\mathrm{cm})$, DEF $=$ Days to $80 \%$ maturity, SPS $=$ No. of seeds per Siliquae, TSW $=$ 1000 seed weight $(\mathrm{g})$ and YPP = Seed yield per plant $(\mathrm{g})$. 
Number of siliquae/plant showed positive significant correlation with yield/plant ( $\mathrm{G}=0.661, \mathrm{P}=0.522)$ and non-significant with days to maturity $(G=0.252, P=0.116)$. Whereas negative significant correlation was found in 1000 -seed weight $(\mathrm{G}=-0.733, \mathrm{P}=-0.068)$ followed by seeds/siliquae $(\mathrm{G}=$ $0.576, \mathrm{P}=-0.112$ ) and negative non-significant values was found in length of siliquae $(\mathrm{G}=-0.114, \mathrm{P}=-0.020)$ (Table 3$)$. Length of siliquae showed positive significant correlation with seeds/siliquae $(G=0.699, P=0.465)$ followed by yield/plant $(G=0.486)$, and showed positive non significant correlation with 1000-seed weight $(G=0.245, P=0.004)$ and days to maturity $(G=0.061, P=0.061)$. Whereas there are no-negative correlation was found for the trait (Table 3).

Days to maturity showed positive non-significant correlation with yield/plant $(G=0.244, P=0.120)$ followed by seeds/siliquae $(G=0.199, P=0.107)$. Whereas negative significant correlation were found in 1000-seed weight $(G=$ 0.956) (Table 3). Shivahare et al. (1975) and Singh et al. (1987) reported that 1000 -seed weight was negatively correlated with days to $80 \%$ maturity. Seeds/siliqua showed positive non-significant correlation with yield/plant ( $\mathrm{G}=$ $0.277, \mathrm{P}=0.146)$ followed by 1000 -seed weight $(\mathrm{P}=0.041)$. Whereas negative non-significant correlation were found in 1000-seed weight $(G=-0.200)$ (Table 3). Dileep et al. (1997) reported that number of siliquae/plant, 1000-seed weight were positively correlated with seed yield. Tyagi et al. (1996) reported that no. of seeds/siliquae had positive and significant effects on seed yield/plant.

Thousand seed weight showed positive non-significant correlation with yield/plant $(\mathrm{P}=0.057)$, but the trait also showed negative significant correlation in genotypic level $(\mathrm{G}=-0.746)$ (Table 3). Saini and Kumar (1995), Kakroo and Kumar (1991) and Olsson (1990) found positive associations which support the results.

\section{Path co-efficient analysis}

Association of character determined by correlation co-efficient may not provide an exact picture of the relative importance of direct and indirect influence of each of yield components on seed yield/plant. In order to find out a clear picture of the inter-relationship between seed yield/plant and other yield attributes, direct and indirect effects were worked out using path analysis at phenotypic level which also measured the relative importance of each component. Seed yield/plant was considered as a resultant (dependent) variable and days to $50 \%$ flowering, days to maturity, plant height, number of primary branches/plant, number of secondary branches/plant, number of siliquae/plant, length of siliquae, number of seeds/siliquae, and 1000-seed weight were causal (independent) variables. Estimation of direct and indirect effect of path co-efficient analysis for Brassica 
rapa is presented in (Table 4). Residual effects of their independent variables, which have influenced on yield to a medium extent, have been denoted as ' $R$ '. The results are discussed briefly as follows:

Path co-efficient analysis revealed that, days to 50\% flowering had negative direct effect (-1.521) on yield/plant. The character had positive indirect effect on on yield/plant through days to maturity (0.525) followed by 1000 -seed weight (0.407), number of secondary branches/plant (0.321), number of siliquae/plant (0.310), number of primary branches/plant 0.159), plant height (0.116), and seeds/siliquae (0.025). And it showed no negative indirect effect on yield (Table 4). Chauhan and Singh (1985) observed positive direct effect of days to $50 \%$ flowering and indirect effect of plant height, primary branches/plant and siliquae/plant on seed yield.

Plant height had the highest positive direct effect (1.572) on yield/plant. The trait had also positive indirect effect via number of primary branches/plant (1.116), seeds/siliquae (0.386), number of secondary branches/plant (0.253), number of siliquae/plant (0.136), 1000-seed weight $(0.125)$, days to $50 \%$ flowering (0.113), days to maturity (0.069), and length of siliquae (0.061). And it showed no negative indirect effect on yield (Table 4). Kumar et al. (1984) and Chen et al. (1983) found negative direct effect on days to maturity.

Primary branches/plant had negative direct effect (-1.239) on seed yield. The character also had the positive indirect effect on yield/plant through plant height (1.417) followed by seeds/siliquae (0.414), and length of siliquae (0.086). Negative indirect effect through secondary branches/plant (-0.181), 1000-seed weight $(-0.061)$ and days to maturity $(-0.039)$ (Table 4). Chauhan and Singh (1995) reported plant height, siliquae/plant, and seeds/siliquae had high positive direct effect on seed yield. Number of secondary branches/plant had positive direct effect (0.827) on yield/plant. This trait had also positive indirect effect on yield via seeds/siliquae (0.643) followed by number of siliquae/plant (0.614), 1000 -seed weight (0.469), number of primary branches/plant (0.271), and days to maturity (0.196). On the other hand, negative indirect effect was found for the character days to $50 \%$ flowering $(-0.591)$ followed by plant height $(-0.480)$ and length of siliquae (-0.036) (Table 4). No. of primary braches/plant had the highest negative direct effect on seed yield was observed by Chowdhury et al. (1987), while working with 42 strains of mustard.

Number of siliquae/plant had positive direct effect (0.553) on seed yield. This trait had also positive indirect effect on yield via number of secondary branches/plant (0.917) followed by seeds/siliquae (0.425), 1000-seed weight 
(0.328), plant height (0.386), and days to maturity (0.158). And this trait had negative indirect effect on days to $50 \%$ flowering $(-0.851)$ followed by number of primary branches/plant (-0.374) and length of siliquae $(-0.030)$ (Table 4). Yadava et al. (1996) found the number of siliquae/plant had the highest positive direct effect on seed yield.

Length of siliquae had direct positive effect (0.261) on yield/plant. This trait had also indirect positive effect on yield/plant through seeds/siliquae (0.516) followed by plant height (0.368) and days to maturity (0.038). On the other hand, length of siliquae showed indirect negative effect via number of primary branches/plant (-0.410), number of secondary branches/plant (-0.113), and 1000seed weight $(-0.109)$, number of siliquae/plant $(-0.063)$, and days to $50 \%$ flowering (-0.002) (Table 4). Days to maturity had direct positive effect (0.262) on yield/plant. This trait also showed indirect positive effect on yield/plant through 1000 -seed weight $(0.427)$ followed by number of secondary branches/plant (0.258), seeds/siliquae (0.147), siliquae/plant (0.139) number of primary branches/plant (0.076), and length of siliquae (0.016). On the other hand, this character showed indirect negative effect via days to $50 \%$ flowering (-1.274) and plant height (-0.172) (Table 4).

Seeds/siliquae had a positive direct effect (0.738) on yield/plant and positive indirect effect via plant height (0.823) followed by siliquae length $(0.183)$, days to maturity (0.125), 1000-seed weight $(0.089)$, and days to $50 \%$ flowering (0.052). On the other hand, this trait showed negative indirect effect through number of secondary branches/plant (-0.720), number of primary branches/plant (-0.694), and siliquae/plant (-0.319) (Table 4). Thousand seed weight had a negative direct effect $(-0.447)$ on yield/plant and positive indirect effect through days to $50 \%$ flowering (1.383) followed by plant height (0.441), seeds/siliquae (0.148) and length of siliquae (0.064).

On the other hand, this trait showed negative indirect effect on yield via number of secondary branches/plant (-0.867), days to maturity (-0.599), siliquae/plant (-0.405), and number of primary branches/plant (-0.168) (Table 4). Kudla (1993) reported that 1000-seed weight had positive direct effect on seed yield. Through path analysis, the residual effect was observed. The residual effect (R) was 0.264 which indicated that characters under study contributed $73.60 \%$ of the variation in seed yield/plant (Table 4). It is suggested that there were some others factors those contributed $26.40 \%$ to the variation in seed yield/plant not included in the present study. Considering the plant height, number of secondary branches, siliquae/plant, maturity duration, seed yield and other yield contributing characters, the genotypes $G_{8}, G_{3}, G_{17}, G_{19}, G_{10}, G_{15}$, and $G_{21}$ were selected for future hybridization programme. 


\section{References}

Behl, R. K., B. D. Chowdhury, R. P. Shingh and D. P. Shingh. 1992. Morphophysiological determinants of oil yield in Brassica juncea under dry land conditions. Indian J. Genet. Pl. Breed. 52 (3): PP. 280-284.

Burton, G. W. 1952. Quantitative inheritance in grass pea. Proc. $6{ }^{\text {th }}$ Grassl. Cong. 1: $277-$ 283.

Chowdhury, B. D., S. K. Thakural, D. P. Singh and P. Singh. 1987. Genetics of yield and its components in Indian mustard. Narenda Deva J. Agril. Res. 3(1): 37-43.

Chauhan, V. S. and P. K. Singh. 1985. Correlation and path analysis in lentil. Lens. 9: 19-22.

Chauhan, J. and P. Singh. 1995. Association of some morpho-physiological determinants with seed yield in Toria (B. campestris L. var. Toria). Thesis Abst. XI-I: 42-43.

Chen, C., K. K. Hwu, C. P. Liu and M. S. Lin. 1983. Selection criteria for yield improvement in rape. J. Agril. Asso. China. 124: 63-73.

Clarke, G. M. 1973. Statistics and Experimental Design. Edward Arnold., London.

Dileep, K., S. V. K. Arvind, D. Bali and K. Kumar. 1997. Correlation and regression studies between different yield attributes and seed yield in mustard (Brassica juncea L.). Pant Univ. Agric. Tech. 14(2): 202-206.

Dewey, D. R. and Lu. 1959. A correlation and path co-efficient analysis of component of crested wheat grass production. Agron. J. 52: 515-518.

Johnson, H. W., H. F. Robinson and R. E. Comstock. 1955. Genetic divergence and relationship in Brassica napus L. Agron. J. 47: 314-318.

Kakroo, P. and S. Kumar. 1991. Genetic determination of seed yield through its components in Indian mustard. Indian J. Genet. Pl. Breed. 51(2): 82.

Khaleque, M. A. 1985. A guide book on production of oil crops in Bangladesh. DAE and FAO/UNDP project BGA/79/034, strengthening the Agricultural Extension Service Khamarbari, Farmgate, Dhaka. P.3.

Kudla, M. 1993. Comperative analysis of winter swede rape genotypes. Biuletyn Instytutu Hodowli Roslin. 90(1): 99-107.

Kumar, P., T. P. Yadava and A. K. Yadav. 1984. Association of seed yield and its component traits in the $\mathrm{F}_{2}$ generation of Indian mustard. Indian J. Agril. Sci. 54(5): 604-607.

Miller, P. J., J. C. Williums, H. F. Robinson and R. E. Comstock. 1958. Estimates of genotypes and environmental variances and covariences in upland cotton and their implications in selection. Agron. J. 50:126-131.

Olsson, G. 1990. Rape yield-production components. Sversk Fortidning. 59(9): 194-197. Cited from Pl. Breed. Abst. 61(5): Pp. 588.

Singh, R. P., B. P. S. Malik and D. P. Singh. 1987. Variation for morphological characters in genotypes of Indian mustard. Indian J. Agril. Sci. 57(4): 225-230. 
Singh, R. K. and B. D. Chowdhury. 1985. Biometrical methods in quantitative genetic analysis. Kalyani Publishers, New Delhi, India. P.56.

Shivahare, M. D., A. B. Singh, Y. S. Chauhan and P. Singh. 1975. Path coefficient analysis of yield component in Indian mustard. Indian J. Agril. Sci. 45(9): 422-425.

Saini, H. C. and R. P. Kumar. 1995. Model plant architecturer through association and path co-efficient analysis in Indian Colza. Indian J. Agril. Res. 29(3): 109115.

Panse, V. G. 1957. Genetics of quantitative characters in relation to plant breeding. Indian J. Genet. 17:318-328.

Rahman, L. 1981. Oil Seed Research \& Development Activities at BAU. Proc. of the workshop on Oil Crop Improvement, BARI. Oilseed Research Project. Ed. By Khaleque M.A., A.B.M. Abul Khair, Md. Ali Akbar and Md. Moszammal Haque. Pp. 25.

Turkey, J. W. 1954. Causation of segregation and path analysis of casual path biometrics. 15: 236-258.

Tyagi, P. K., K. Singh, V. Rao and A. Kumar. 1996. Correlation and path co-efficient analysis in Indian mustard (Brassica juncea L.). Crop Res. Hisar 11(3): 319-322.

Wright, S. 1959. Theory of path co-efficient. Genetics 8: 239-255.

Yadava, T. P., A. K. Yadav and H. Singh. 1978. A concept of plant Ideotype in Indian mustard (B. juncea L. Czern and Coss). $5^{\text {th }}$ International Rapeseed Conf, June. 1978: P. 7.

Yadava, O. P., T. P. Yadav and P. Kumar. 1996.Combining ability studies for seed yield, its components characters and oil content in Indian mustard (Brassica juncea L. Czern and Coss.). J. Oil Seed Res. 9(1): 14-20. 